\title{
FORMULASI SEDIAAN OBAT KUMUR EKSTRAK ETANOL DAUN SELASIH (Ocimum basilicum L.) SEBAGAI UJI AKTIVITAS ANTIBAKTERI Streptococcus mutans
}

\author{
Adel Fina Oktaviani ${ }^{* 1}$, St. Rahmatullah ${ }^{2}$, Dwi Bagus Pambudi ${ }^{3}$ \\ ${ }^{*}, 2,3$ Program Studi Sarjana Farmasi, Fakultas Ilmu Kesehatan, Universitas Muhammadiyah Pekajangan \\ Pekalongan \\ e-mail: ${ }^{* 1}$ adelfina347@gmail.com, ${ }^{2}$ amma88.an@gmail.com, ${ }^{3}$ dwibagus589@gmail.com.
}

\begin{abstract}
ABSTRAK
Tanaman selasih (Ocimum basilicum L.) merupakan tanaman yang memiliki khasiat terutama pada bagian daunnya yaitu sebagai antibakteri. Kandungan senyawa aktif daun selasih yaitu eugenol, metal eugenol, linalool, geraniol, anetol, eucaliptol dan metal sinnamat. Obat kumur dapat digunakan untuk menjaga kesegaran nafas atau mengatasi penyakit yang ada di dalam rongga mulut. Tujuan dari penelitian ini untuk mengetahui pengaruh ekstrak etanol daun selasih (Ocimum basilicum L.) yang di buat dalam sediaan obat kumur terhadap bakteri Streptococcus mutans dan untuk mengetahui zona hambat tiap konsentrasinya. Metode yang digunakan yaitu metode eksperimental dengan menggunakan metode difusi cakram. Konsentrasi ekstrak etanol daun selasih 13\%, 15\%, dan 17\%. Kontrol positif obat kumur listerin (Cool mint) dan kontrol negatif sediaan obat kumur tanpa ekstrak. Evaluasi sediaan obat kumur ekstrak etanol daun selasih (Ocimum basilicum L.) seperti uji organoleptis, uji pH, uji homogenitas, uji viskositas, uji stabilitas dan uji zona hambat bakteri. Kesimpulan formula sediaan obat kumur ekstrak etanol daun selasih menunjukkan hasil uji sediaan sesuai dengan literatur kecuali uji viskositas. Formula sediaan obat kumur ekstrak daun selasih (Ocimum basilicum L.) memiliki daya hambat pada bakteri Streptococcus mutans dengan zona hambat sebesar $4 \mathrm{~mm}$ pada formula I, formula II 4,8 mm, dan formula III 9,15 mm.
\end{abstract}

Kata kunci: Aktivitas, Daun Selasih, Obat Kumur, Streptococcus Mutans.

\begin{abstract}
Basil plant (Ocimum basilicum L.) is a plant that has properties, especially in the leaves, namely as an antibacterial. The active compounds in basil leaves are eugenol, linalool, geraniol, anetol, eucaliptol, metal cinnamate. Mouthwash can be used to maintain breath freshness or treat diseases that exist in the oral cavity. The purpose of this study was to determine the effect of ethanol extract of basil leaves made in mouthwash preparations againts Streptococcus mutans bacteria and to determine the inhibition zone of each concentration. The method used is an experimental method using the disc diffusion method. The concentration of basil leaf ethanol extract was 13\%,15\% and 17\%. Positive control of listerin mouthwash (Cool mint) and negative control of mouthwash without extract. Evaluation of mouthwash of basil leaf ethanol extract were the organoleptic test, pH test, homogeneity test, viscosity test, stability test and bacterial inhibition zone test. The result showed that the evaluations of the formulation mouthwash of basil leaf extract were in accordance with the literature except for the viscosity test. The oral formulation had an inhibitory power on Streptococcus mutans bacteria with an inhibition zone of $4 \mathrm{~mm}$ in formula I, formula II 4,8 $\mathrm{mm}$, and formula III $9,15 \mathrm{~mm}$.
\end{abstract}

Keywords: Activity, Basil Leaves, Mouthwash, Streptococcus mutans.

\section{PENDAHULUAN}

Kesehatan rongga mulut merupakan suatu hal yang paling bagi masyarakat karena keadaan mulut yang sehat bisa melakukan aktivitas sehari-hari seperti makan, berbicara, dan bersosialisasi tanpa mengalami rasa sakit dan tidak nyaman. Masalah kesehatan mulut yang sering terjadi yaitu bau mulut, infeksi mulut dan sariawan. Selain itu, masalah mulut lainnya yang lebih 
kompleks yaitu mulut kering, radang gusi dan kanker mulut [1]. Penyakit rongga mulut yang mengganggu kesehatan gigi yang cukup umum yaitu masalah karies gigi dan penyakit periodontal [2]. Bakteri yang paling banyak tumbuh di dalam rongga mulut adalah Streptococcus sp, yang merupakan tahap awal terjadinya karies gigi. Streptococcus mutans merupakan suatu bakteri asidogenik yang menghasilkan senyawa asam, yang menyebabkan penimbunan senyawa asam pada gigi, sehingga terjadinya dekalsifikasi (hilangnya kalsium) dan terkikisnya permukaan gigi yang dapat menyebabkan karies gigi.

Cara mengatasi berbagai penyakit dalam rongga mulut yaitu menggunakan obat kumur. Obat kumur adalah larutan air yang digunakan untuk meningkatkan kesehatan rongga mulut, estetika, pembersih dan kesegaran nafas [3]. Obat kumur yang beredar di pasaran sebagian besar mengandung alkohol yang dapat menimbulkan efek samping jika penggunan jangka panjang. Pemanfaatan bahan alam dibutuhkan sebagai bahan alternatif lain yang dapat mengurangi efek samping dari alkohol seperti ekstrak daun selasih (Ocimum basilicum L.).

Daun selasih (Ocimum basilicum L.) merupakan salah satu tumbuhan yang memiliki aktivitas antibakteri. Senyawa aktif yang terkandung dalam daun selasih antara lain yaitu eugenol, metal eugenol, osimen, alfa pinen, eucaliptol, linalool, geraniol, metal sinnamat, anetol, dan campor [4]. Ekstrak etanol dari daun selasih (Ocimum basilicum L.) secara ilmiah telah diteliti mempunyai aktivitas terhadap bakteri Escherichia coli dengan konsentrasi $3 \mathrm{mg} / \mathrm{sumuran}$ memiliki diameter zona hambat $8,5 \mathrm{~mm}$, sedangkan pada bakteri Staphylococcus aureus dengan konsentrasi $3 \mathrm{mg} /$ sumuran memiliki daya hambat 11,2 $\mathrm{mm}$ [4].

Banyaknya manfaat daun selasih terutama untuk penghambat bakteri Escherichia coli dan Staphylococcus aureus. Pemanfaatan ekstrak daun selasih belum ada sebagai penghambat bakteri dan zat aktif pada sediaan obat kumur, yang digunakan untuk menjaga kesegaran nafas. Salah satu bakteri penyebab penyakit di dalam rongga mulut yaitu Streptococcus mutans. Bakteri Streptococcus mutans belum dilakukan penelitian uji aktivitas antibakteri pada ekstrak daun selasih (Ocimum basilicum L.) yang dibuat sediaan obat kumur. Masih banyak masyarakat sekitar yang belum mengetahui manfaat dari daun selasih, mereka hanya memanfaatkan daun selasih sebagai bunga tabur untuk kegiatan nyekar saat akhir bulan ramadhan. Berdasarkan uraian diatas, peneliti memiliki inovasi untuk memanfaatkan daun selasih sebagai obat kumur. Hasil penelitian ini diharapkan dapat menghasilkan data pada formula obat kumur yang memiliki kualitas fisik yang baik, berkhasiat serta lebih aman jika digunakan oleh masyarakat.

\section{METODE PENELITIAN}

Pada penelitian ini menggunakan desain penelitian eksperimental dengan metode difusi cakram disc. Sampel yang digunakan adalah ekstrak daun selasih (Ocimum basilicum L.) dan dianalisis dengan cara mengevaluasi sediaan obat kumur ekstrak etanol daun selasih (Ocimum basilicum L.) dan nilai zona hambat bakteri menggunakan metode analisis One Way Analysis of Variance (ANOVA). Penelitian ini dilaksanakan di laboratorium kimia, laboratorium mikrobiologi dan laboratorium farmakognosi dan fitokimia Prodi Sarjana Farmasi Universitas Muhammadiyah Pekajangan Pekalongan.

\subsection{Alat dan Bahan}

Alat yang digunakan dalam penelitian ini adalah bejana maserasi, alat-alat gelas laboratorium, neraca analitik (OHAUSE), blender (Cosmos), autoklaf, inkubator, oven, LAF, rotary evaporator (Heidolph), lemari pendingin (Modena), cakram disc blank. 
Bahan- bahan yang akan digunakan dalam penelitian ini adalah daun selasih (Ocimum basilicum L.) yang diperoleh dari petani di desa Kedungmiri Kabupaten Batang, waktu pengambilan pada jam 9 pagi. Gliserin, natrium sakarin, peppermint oil, tween 80 , aquadest steril, etanol $96 \%$, listerine (Cool Mint), $\mathrm{HCL}$, serbuk $\mathrm{Mg}$, kloroform, $\mathrm{H}_{2} \mathrm{SO}_{4}$, pereaksi Mayer, asam asetat anhidrat, $\mathrm{NB}, \mathrm{BaCl}_{2} 2 \mathrm{H}_{2} \mathrm{O}$, NA (Nutrients Agar), bakteri Streptococcus mutans.

\subsection{Jalannya Penelitian \\ Deterrminasi}

Determinasi daun selasih dilakukan di Universitas Ahmad Dahlan. Daun selasih (Ocimum basilicum L.) yang digunakan penelitian diperoleh dari daerah Kedungmiri Kabupaten Batang.

\section{Pembuatan simplisia}

Daun selasih sebanyak $4 \mathrm{~kg}$ dibersihkan dengan air mengalir. Daun setelah bersih di potong, kemudian dikeringkan didalam oven pada suhu $40^{\circ} \mathrm{C}-60^{\circ} \mathrm{C}$ selama 24 jam atau sampai kering. Simplisia disortasi kemudian diblender hingga menjadi simplisia serbuk dan diayak dengan menggunakan ayakan mesh 40 lalu ditimbang. Serbuk di simpan dalam wadah yang bersih dan kering. Uji penetapan kadar air dilakukan menggunakan alat moisture balance.

\section{Pembuatan ekstrak}

Pembuatan ekstrak daun selasih dilakukan dengan metode maserasi yaitu serbuk daun selasih ditimbang sebanyak $600 \mathrm{~g}$ dimasukkan kedalam wadah dan tambahkan $3000 \mathrm{~mL}$ pelarut etanol $96 \%$. Ditutup dan dimaserasi selama 5 hari, tiap harinya diaduk selama 1 jam. Ekstrak disaring dengan menggunakan kertas saring sehingga didapat maserat (filtrat I). Ampas dari filtrat pertama diremaserasi dengan etanol $96 \%$ sebanyak $1800 \mathrm{~mL}$ (filtrat II). Filtrat I dan filtrat II digabungkan lalu diuapkan dengan menggunakan rotary evaporator dan dilanjutkan dengan penguapan oven pada suhu $40^{\circ} \mathrm{C}$ sehingga diperoleh ekstrak kental.

\section{Skrining fitokimia ekstrak daun selasih Identifikasi flavonoid}

Larutkan ekstrak daun selasih (Ocimum basilicum L.) sebanyak 0,5 gram ke dalam $2 \mathrm{~mL}$ etanol, tambahkan serbuk Mg 0,5 g dan 3 tetes HCL pekat. Apabila positif senyawa flavon terbentuk warna jingga sampai merah, warna merah sampai merah padam menunjukkan flavanol, warna merah padam sampai merah keunguan menunjukkan flavanon [5].

\section{Identifikasi alkaloid}

0,5 gram ekstrak daun selasih di masukkan ke dalam tabung reaksi, tambahkan $2 \mathrm{~mL}$ etanol kemudian diaduk. Tambahkan $5 \mathrm{~mL}$ HCL $2 \mathrm{~N}$, dipanaskan pada penangas air. Tunggu sampai dingin, setelah itu disaring dan filtrat ditambahkan beberapa tetes reagen Mayer. Sampel diamati, jika keruh atau ada endapan berarti positif [5].

\section{Identifikasi steroid}

0,5 gram ekstrak daun selasih dimasukan ke dalam tabung reaksi kemudian tambahkan 2 $\mathrm{mL}$ etanol diaduk. Tambahkan $2 \mathrm{~mL}$ kloroform, $2 \mathrm{~mL} \mathrm{H}_{2} \mathrm{SO}_{4}$ pekat ditambahkan dengan cara diteteskan pelan-pelan dari sisi dinding tabung reaksi. Adanya senyawa steroid terbentuknya cincin warna merah [5].

\section{Identifikasi terpenoid}

$0,5 \mathrm{~g}$ ekstrak daun selasih dalam tabung reaksi ditambahkan $2 \mathrm{~mL}$ etanol kemudian dikocok, tambahkan $1 \mathrm{~mL}$ kloroform dan $1 \mathrm{~mL}$ asetat anhidrida. Setelah dingin ditambahkan $\mathrm{H}_{2} \mathrm{SO}_{4}$. Jika terbentuk warna kemerahan menunjukkan adanya senyawa terpenoid [5].

\section{Pembuatan formulasi obat kumur ekstrak daun selasih}


Rancangan formulasi obat kumur dibuat dengan mengacu pada formula Masdiari Pane (2019) [6] kemudiaan dimodifikasi dengan mengganti jenis ekstrak yang akan digunakan yaitu ekstrak daun selasih (Ocimum basilicum L.). Formulasi dapat dilihat pada tabel di bawah ini:

\begin{tabular}{ccccc} 
Tabel I. Rancangan Formulasi Obat Kumur Ekstrak Etanol Daun Selasih \\
\hline Bahan & \multicolumn{5}{c}{ Formula } & Fungsi \\
\cline { 2 - 5 } & F 1 & F 2 & F 3 & \\
\hline Ekstrak & $13 \%$ & $15 \%$ & $17 \%$ & Zat akif \\
Sakarin & $0,3 \%$ & $0,3 \%$ & $0,3 \%$ & Pemanis \\
Tween 80 & $5 \%$ & $5 \%$ & $5 \%$ & Surfaktan \\
Gliserin & $1 \%$ & $1 \%$ & $1 \%$ & Humektan \\
Peppermint oil & $0,3 \%$ & $0,3 \%$ & $0,3 \%$ & Flavors \\
Aquadest ad & $50 \mathrm{~mL}$ & $50 \mathrm{~mL}$ & $50 \mathrm{~mL}$ & Pelarut \\
\hline
\end{tabular}

Pembuatan obat kumur pertama disiapkan alat-alat yang akan digunakan, semua bahan ditimbang sesuai kebutuhan. Dimasukkan ekstrak daun selasih kedalam mortir, ditambahkan gliserin dan tween 80 dan gerus ad homogen. Tambahkan sakarin aduk sampai homogen. Dimasukan sebagian aquadest sedikit demi sedikit hingga semua ekstrak larut sempurna, tambahkan peppermint oil. Ditambahkan aquadest hingga $50 \mathrm{~mL}$, kemudian larutan disaring dan dimasukan kedalam botol.

\section{Evaluasi sediaan obat kumur \\ Uji organoleptis \\ Pemeriksaan organoleptis meliputi pemeriksaan bentuk, warna, bau dan rasa.}

\section{Uji pH}

Pengukuran $\mathrm{pH}$ menggunakan alat $\mathrm{pH}$ meter yang sebelumnya dibilas dengan aquadest, kemudian dikeringkan dengan tissue. Masukkam alat $\mathrm{pH}$ meter kedalam sediaan obat kumur, tunggu sampai diperoleh hasil $\mathrm{pH}$ yang stabil.

\section{Uji homogenitas}

Amati tekstur atau keseragaman partikelnya sediaan yang sudah jadi. Catat hasilnya.

\section{Uji viskositas}

Pengukuran viskositas sediaan obat kumur dilakukan menggunakan viskometer. Alat viskometer diset terlebih dahulu, rotor yang digunakan No. 2 dengan kecepatan $60 \mathrm{rpm}$. Siapkan sampel, dicelupkan sampai tanda batas rotor. Viskometer dinyalakan selama kurang lebih 10 detik, setelah ditetapkan hasilnya alat dimatikan. Hasil viskositas dihitung.

\section{Uji stabilitas}


Pengujian stabilitas menggunakan metode uji sentrifugasi dengan cara $2 \mathrm{ml}$ sediaan dimasukkan kedalam tabung sentrifugasi. Atur kecepatan 3000 rpm selama 30 menit. Hasil diamati adanya pemisahan atau tidak.

\section{Uji aktivitas antibakteri \\ Sterilisasi alat}

Alat-alat yang digunakan dalam uji aktivitas antibakteri ini disterilkan terlebih dahulu. Alat-alat gelas dan media disterilkan dalam autoklaf pada suhu $121^{\circ} \mathrm{C}$ selama $15-20$ menit, sedangkan untuk jarum Ose dan pinset disterilisasikan dengan cara dibakar diatas api langsung.

\section{Pembuatan Nutrient Broth}

Ditimbang sebanyak 0,16 g, tambahkan aquadest $20 \mathrm{~mL}$ ke dalam erlenmayer. Homogenkan dengan stirer dan hot plate. NB yang sudah homogen dimasukkan ke dalam tabung reaksi.

\section{Pembuatan media Nutrient Agar (NA)}

Nutrient Agar (NA) sebanyak 3,5 gram dilarutkan dalam $175 \mathrm{~mL}$ aquadest $(20 \mathrm{~g} / 1000$ $\mathrm{mL}$ ) menggunakan erlenmeyer. Setelah itu, dihomogenkan dengan stirer dan alat hot plate sampai mendidih. Media yang telah dihomogenkan kemudiaan dimasukkan ke dalam cawan petri steril $25 \mathrm{~mL}$.

\section{Pembuatan suspensi bakteri Streptococcus mutans}

Bakteri uji yang telah diinokulasi pada media agar kemudian diambil dengan kawat Ose steril lalu disuspensikan kedalam tabung yang berisi $5 \mathrm{~mL}$ larutan NB.

\section{Pembuatan larutan sampel}

Ekstrak daun selasih (Ocimum basilicum L.) dengan konsentrasi $13 \%, 15 \%$, dan $17 \%$ ditimbang, kemudian tambahkan DMSO sebanyak $250 \mu$ laduk ad larut.

\section{Uji daya hambat Streptococcus mutans}

Sedian obat kumur dengan konsentrasi ekstrak etanol daun selasih $13 \%, 15 \%$, dan $17 \%$ dilakukan uji daya hambat bakteri Streptococcus mutans. Dimasukkan media agar NA $25 \mathrm{~mL}$ kedalam cawan petri steril, kemudian dituang suspensi bakteri sebanyak $0,1 \mathrm{~mL}$ ke dalam cawan petri yang berisi medium agar cair, dihomogenkan dengan cara digoyangkan membentuk angka 8, tunggu sampai memadat. Selanjutnya kertas cakram yang sudah direndam dengan larutan sediaan obat kumur ekstrak etanol daun selasih diletakkan pada permukaan media agar padat yang sudah ditandai. Media dibungkus kertas dan dinkubasi pada inkubator suhu $37^{\circ} \mathrm{C}$ selama 24 jam. Amati dan hitung zona hambat bakteri menggunakan jangka sorong. Kontrol negatif menggunakan larutan formulasi obat kumur tanpa ekstrak daun selasih, sedangkan kontrol positifnya menggunakan obat kumur listerine (Cool Mint). Tiap formulasi dilakukan 3 kali replikasi.

\subsection{Analisis Data}

Penelitian ini merupakan eksperimental laboratorium. Hasil data pengamatan pada evaluasi sediaan obat kumur ekstrak etanol daun selasih (Ocimum basilicum L.) dan zona hambat terhadap bakteri Streptococcus mutans menggunakan metode analisis One Way Analysis of Variance (ANOVA).

\section{HASIL DAN PEMBAHASAN}

Tanaman yang digunakan dalam penelitian ini adalah tanaman selasih (Ocimum basilicum L.). Bagian tanaman yang digunakan untuk penelitian yaitu daun. Tanaman selasih diperoleh dari desa Kedungmiri, Kecamatan Batang, Kabupaten Batang, Jawa Tengah. Sampel tanaman selasih dilakukan determinasi untuk mengetahui keaslian tanaman tersebut dan klasifikasinya, sehingga tidak adanya kesalahan dalam pengambilan tanaman yang digunakan dalam penelitian. Determinasi tanaman dilakukan di Laboratorium Biologi Universitas Ahmad 
Dahlan. Dari hasil determinasi tersebut menyatakan bahwa benar tanaman tersebut tanaman selasih.

Pada proses pembuatan simplisia terdapat beberapa tahapan, yang pertama pengumpulan bahan baku dimana bahan baku di dapatkan dari perkebunan salah satu milik warga desa Kedungmiri. Proses selanjutnya sortasi basah yang dilakukan dengan menghilangkan kotoran atau bahan-bahan asing yang menempel di bahan baku. Daun selasih (Ocimum basilicum L.) di cuci dengan air bersih yang mengalir, kemudian bagian daun yang besar di potong-potong agar mempermudah pengeringan. Tahap berikutnya pengeringan, daun selasih (Ocimum basilicum L.) dikeringkan menggunakan oven dengan suhu $50^{\circ} \mathrm{C}$ selama 2 hari. Tahap selanjutnya sortasi kering dengan cara memisahkan bagian benda asing atau kotoran lainnya yang masih tertinggal pada simplisisa kering. Daun selasih (Ocimum basilicum L.) yang masih basah $4 \mathrm{~kg}$, setelah dilakukan pengeringan berat yang diperoleh sebanyak $2 \mathrm{~kg}$, dengan penyusutan pengeringan $50 \%$. Kadar air simplisia yang diperoleh 5,94\% sesuai dengan syarat mutu yaitu $<10 \%$ [7]. Tahap selanjutnya simplisia kering dihaluskan menggunakan blender dan diayak dengan ayakan berukuran 40 mesh.

Serbuk daun selasih sebanyak 600 gram dimasukkan ke dalam bejana kaca dan ditambahkan $3000 \mathrm{~mL}$ pelarut etanol 96\%. Proses maserasi selama 5 hari dan tiap harinya diaduk selama 1 jam. Proses selanjutnya remaserasi selama 2 hari, larutan di saring dan diperas, filtrat maserasi dan remaserasi jadikan satu. Filtrat di evaporasi menggunakan alat rotary evaporator dengan suhu $40^{\circ} \mathrm{C}$ untuk menguapkan etanol dan memekatkan filtrat, kemudiaan di oven dengan suhu $60^{\circ} \mathrm{C}$ sampai terbentuk ekstrak kental.

Tabel II. Rendemen Ekstrak Daun Selasih (Ocimum basilicum L.) Hasil Ekstrak

\begin{tabular}{lcccc}
\cline { 2 - 4 } \multicolumn{1}{c}{ Bahan } & Serbuk & Warna & Bobot & Rendemen \\
\hline $\begin{array}{l}\text { Simplisia daun selasih } \\
\text { (Ocimum basilicum L. })\end{array}$ & $600 \mathrm{~g}$ & Hitam & $85,34 \mathrm{~g}$ & $14,22 \%$ \\
\hline
\end{tabular}

(Sumber : Data Primer 2021)

Skrining fitokimia dilakukan untuk mengidentifikasi zat-zat aktif yang terdapat di dalam ekstrak daun selasih (Ocimum basilicum L.). Uji skrining fitokimianya meliputi uji flavonoid, uji alkaloid, uji steroid, dan uji terpenoid. Hasil uji skrining menunjukkan hasil positif semuanya.

Tabel III. Uji Skrining Fitokimia Ekstrak Daun Selasih (Ocimum basilicum L.)

\begin{tabular}{cccc}
\hline No & Senyawa & Hasil & Keterangan \\
\hline 1 & Flavonoid & + & Merah kecoklatan \\
2 & Alkaloid & + & Jingga dan endapan \\
3 & Steroid & + & Cincin merah kecoklatan \\
4 & Terpenoid & + & Merah \\
\hline
\end{tabular}

Keterangan :

(Sumber : Data Primer, 2021)

$(+)$ : teridentifikasi

$(-)$ : tidak teridentifikasi

Hasil uji organoleptis sediaan obat kumur ekstrak daun selasih (Ocimum basilicum L.) pada formula 1 yaitu bentuknya cair, warna hitam, bau mint, rasanya manis dan mint. Pada formula 2 bentuknya cair, warna hitam, bau mint, rasanya pahit dan mint. Pada formula 3 sediaan berbentuk cair, warna hitam, baunya mint, rasa pahit dan mint. Dari data tersebut dapat dikatakan bahwa semakin tinggi konsentrasi ekstrak dapat mempengaruhi rasa dan warna.

Hasil dari uji homogenitas pada formula 1 dengan konsentrasi ekstrak $13 \%$, formula 2 konsentrasi ekstrak $15 \%$ dan formula 3 dengan konsentrasi ekstrak $17 \%$ menunjukkan sediaan yang homogen, karena tidak terdapat partikel-partikel di sediaan dan tidak terjadi pemisahan.

Jurnal Ilmiah Jophus Vol. 03, No. 01, Agustus 2021 : 1 - 9 
Sediaan yang baik adalah sediaan yang homogen yang tidak terdapat partikel-partikel pada sediaan dan terdispersi merata dalam sediaan secara keseluruhan sehingga jika digunakan untuk pengobatan, dosis yang diterima sesuai atau merata [8].

Uji $\mathrm{pH}$ menggunakan alat $\mathrm{pH}$ meter. Hasil pemeriksaan $\mathrm{pH}$ sediaan obat kumur daun selasih (Ocimum basilicum L.) pada formula 1 konsentrasi ekstrak 13\%, formula 2 dengan konsentrasi ekstrak $15 \%$ dan formula 3 konsentrasi ekstrak $17 \%$ memiliki pH yang sama yaitu 5. Menurut penelitian Danamik (2017) [9] mengatakan bahwa syarat $\mathrm{pH}$ obat kumur yaitu 4.0-6,5, jadi hasil pH sediaan obat kumur ekstrak daun selasih (Ocimum basilicum L.) memenuhi syarat yang sudah ditetapkan. Hasil uji $\mathrm{pH}$ dapat dilihat pada grafik dibawah ini:

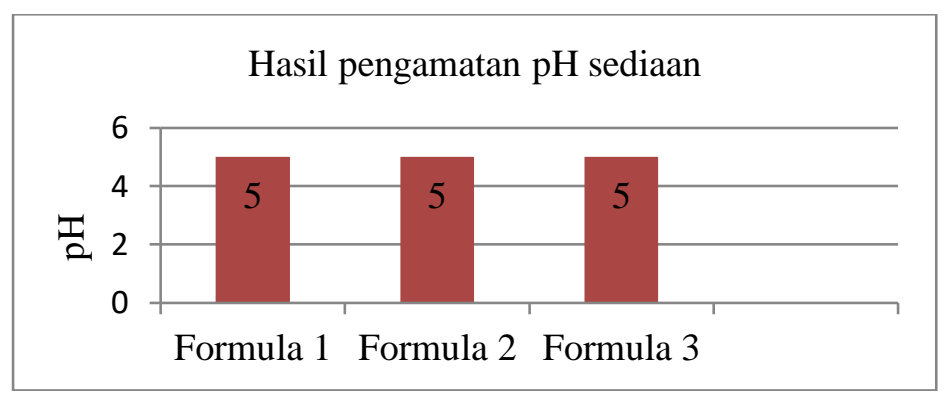

Gambar 1. Hasil Uji pH Sediaan Obat Kumur

Hasil uji stabilitas pada formula I, II dan III tidak terjadi pemisahan, hal tersebut dapat dikatakan bahwa sediaanya stabil. Stabilitas pada bentuk sediaan obat lebih ditujukan pada kemampuan produk untuk mempertahankan sifat dan karakteristik khasiat atau terapi agar tetap sama pada saat dibuat sampai batasan yang ditetapkan sepanjang periode penyimpanan dan penggunaan (shelf-life) [10].

Hasil uji viskositas pada formula 1 dengan konsentrasi $13 \%$ yaitu 9 m.paS, formula 2 konsentrasi $15 \%$ sebanyak 6,33 m.paS dan formula 3 dengan konsentrasi $17 \%$ diperoleh viskositas 4,3 m.paS. Menurut penelitian Handayani (2017) [3] bahwa viskositas sediaan mouthwas mendekati $\pm 1 \mathrm{cp}$. Hasil viskositas yang diperoleh melebih syarat viskositas yang telah ditetapkan.

Pengukuran zona hambat yang terbentuk menggunakan jangka sorong dengan ketelitian milimeter (mm). Hasil pengukuran zona hambat sediaan obat kumur ekstrak daun selasih (Ocimum basilicum L.) dapat dilihat di bawah ini :

Tabel IV. Hasil Uji Zona Hambat Sediaan Obat Kumur Ekstrak Daun Selasih (Ocimum basilicum L.)

\begin{tabular}{cccccc}
\hline Formula & Ekstrak & \multicolumn{4}{c}{ Zona Hambat $(\mathbf{m m})$} \\
\cline { 3 - 6 } & & $\mathbf{1}$ & $\mathbf{2}$ & $\mathbf{3}$ & Rata-rata \pm SD \\
\hline F 1 & $13 \%$ & 3,9 & 4,2 & 3,9 & $4 \pm 0,173205$ \\
F 2 & $15 \%$ & 4,9 & 4,9 & 4,6 & $4,8 \pm 0,057735$ \\
F 3 & $17 \%$ & 10 & 11,4 & 6,06 & $9,15 \pm 2,768851$ \\
K + & Listerin & 18,3 & 18,3 & 18,3 & $18,3 \pm 0$ \\
K - & - & 0 & 0 & 0 & $0 \pm 0$ \\
\hline
\end{tabular}

Hasil pengamatan uji antibakteri yang diperoleh dengan rata-rata hambatan yang berbeda-beda dan mempunyai kriteria kekuatan antibakteri yang berbeda juga. Pada formula 1 dengan konsentrasi ekstrak $13 \%$ menghasilkan zona hambat $4 \mathrm{~mm}$. Pada formula 2 konsentrasi ekstrak $15 \%$ sebesar 4,8 mm, formula 3 sebesar 9,15 mm dengan konsentrasi $17 \%$, sedangkan zona hambat kontrol positif diperoleh sebesar $18,3 \mathrm{~mm}$. Dari hasil zona hambat tersebut, ketiga 
formula yang memiliki kekuatan antibakteri lemah pada formula 1 dan 2, sedangkan formula 3 kekuatan antibakterinya termasuk sedang. Kriteria kekuatan antibakteri pada diameter zona hambat > $20 \mathrm{~mm}$ sangat kuat, 10-20 mm daya hambat bakteri kuat, 5-10 mm daya hambat sedang, dan diameter zona hambat 0-5 mm termasuk lemah [11]. Berdasarkan hasil analisis diatas, ekstrak daun selasih (Ocimum basilicum L.) dengan konsentrasi tinggi memiliki daya hambat yang lemah kemungkinan karena faktor lingkungan tumbuh tanaman, usia tumbuhan saat dipanen, usia daun dan waktu panen, sehingga mempengaruhi kadar senyawa metabolit sekunder yang terkandung di dalam tumbuhan [11].

Berdasarkan hasil analisis statistik uji normalitas homogenitas diperoleh nilai signifikansi $>0,05$ yang artinya terdistrubusi normal dan homogen, sehingga dilanjutkan dengan uji stastitik ANOVA yang menghasilkan nilai signifikansi > 0,05 yang menyatakan tidak ada perbedaan pada formula.

\section{KESIMPULAN}

Hasil data yang diperoleh dapat disimpulkan bahwa formula sediaan obat kumur ekstrak daun selasih (Ocimum basilicum L.) setelah dilakukan uji evaluasi sediaan baik organoleptis, $\mathrm{pH}$,, homogenitas, stabilitas memenuhi persyaratan yang telah ditetapkan kecuali uji viskositas. Formula sediaan obat kumur ekstrak daun selasih (Ocimum basilicum L.) memiliki daya hambat pada bakteri Streptococcus mutans. Formula I konsentrasi $13 \%$ zona hambat sebesar $4 \mathrm{~mm}$, formula II konsentrasi $15 \%$ sebesar $4,8 \mathrm{~mm}$, dan formula III konsentrasi $17 \%$ zona hambatnya $9,15 \mathrm{~mm}$.

\section{DAFTAR PUSTAKA}

[1] Zahrah, F, Formulasi dan Uji Aktivitas Antibakteri Staphylococcus aureus Pada Sediaan Obat Kumur Berbasis Non Partikel Perak, skripsi, Fakultas Kesehatan dan Ilmu Kesehatan, UIN Maulana Malik Ibrahim, 2018. Malang.

[2] Mardiana, Pengembangan Produk Mouthwash Berbasis Ekstrak Etanol Bekatul Beras Putih (oryza sativa L.) Sebagai Antibakteri Streptococcus mutans dan Porphyromonas gingivalis, skripsi, Fakultas Kedokteran Gigi, Universitas Hasanuddin, 2017, Makasar

[3] Handayani, F., Sundu, R., \& Sari, R. M, "Formulasi dan Uji Aktivitas Antibakteri Streptococcus mutans dari Sediaan Mouthwash Ekstrak Jambu Biji (Psidium guajava L.)", jurnal, vol. 1, No 8, pp 422-433, 2017, [online]. Available: https://doi.org/10.25026/jsk.vli8.62.

[4] Aristiana, F.D, Aktivitas Antibakteri Ekstrak Etanol Daun Selasih (Ocimum basilicum L.) Terhadap Escherichia coli Sensitif dan Multiresisten Antibiotik, skripsi, Fakultas Farmasi, UMS, 2012, Surakarta.

[5] Khoirani, N, Karakterisasi Simplisia Dan Standarisasi Ekstrak Etanol Herba Kemangi (Ocimum americanum L.), skripsi, Fakultas Kedokteran Dan Ilmu Kesehatan, UIN Syarif Hidayatullah, 2013, Jakarta.

[6] Pane, M, Formulasi Sediaan Obat Kumur Ekstrak Teh Hijau (Camellia sinensis (L.) Kuntze), skripsi, Fakultas Farmasi, Universitas Sumatera Utara, 2019, Medan.

[7] Utami, Pratiwi Yuri, et al., "Standardisasi Simplisia dan Ekstrak Etanol Daun Leilem (Clerodendrum minahassae Teisjm. \& Binn.)", jurnal, vol. 2(1), pp 32-39, 2017, [online]. Available: https://www.jpms-stifa.com.

[8] Pratama, ega, adilla edi arief, "Formulasi Sediaan Gargarisma dari Ekstrak Buah Belimbing Wuluh (Averrhoa bilimb L.) Sebagai Anti Kandidiasis", jurnal, vol. 3(2), 2018, pp. 11-16, 2018, [online]. Available: http://ojs.stikes.muhammadiyahku.ac.id/index.php/jfarmaku.

[9] Damanik, A.D, Uji Aktivitas Antibakteri Dari Ekstrak Etanol Daun Situduh Langit (Erigeron Sumatrensis Retz), skripsi, Fakultas Farmasi, Universitas Sumatra Utara, 2017, Medan. 
[10] Rismana, Eriawan, et al, "Pengujian Stabilitas Sediaan Antiacne Berbahan Baku Aktif Nanopartikel Kitosan/Ekstrak Manggis-Pegagan”, jurnal, vol. 41, No 4, pp 207-216, 2013 , [online]. Available: http://ejournal.litbang.kemkes.go.id.

[11] Febrianasari, F, Uji Aktivitas Antibakteri Ekstrak Daun Kirinyu (Chromolaena odorata) Terhadap Staphylococcus aureus, skripsi, Fakultas keguruan dan Ilmu Pendidikan, Universitas Sanata Dharma, 2018, Yogyakarta. 